\title{
Practices used by a home care team: implications for caregivers
}

\author{
Práticas utilizadas pela equipe do Serviço de Atenção Domiciliar: implicações sobre os cuidadores \\ Prácticas utilizadas por el equipo de atención domiciliaria: implicaciones para los cuidadores
}

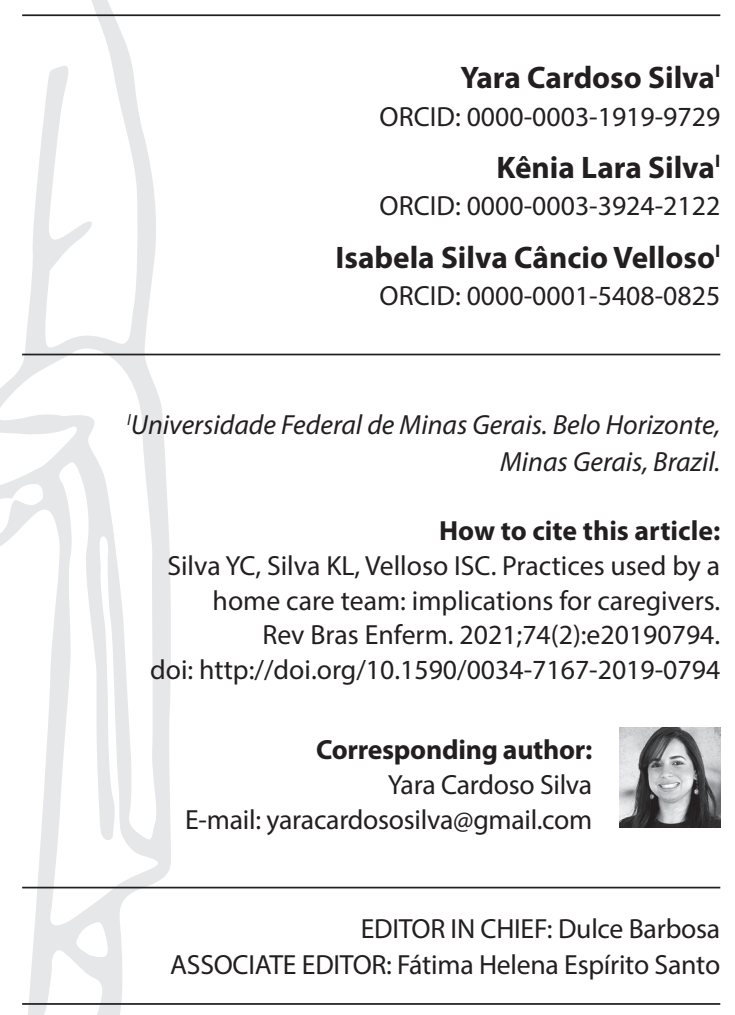

Submission: $02-22-2020$

Approval: $10-31-2020$

\begin{abstract}
Objectives: to analyze the practices of a home care team and their implications for caregivers' performance. Methods: qualitative study with data obtained from observation of 21 users, 30 caregivers and 6 professionals from the home health care service in a municipality in Minas Gerais, from February to June 2018. The material was analyzed from the perspective of discourse analysis according to Michel Foucault. Results: team interference upon caregivers is exercised by disciplinary practices and prescriptive, authoritative and surveilling behaviors. The team's knowledge-power relationship determines caregivers' acceptance through convincing or through difficulty of understanding assigned orientations. Educational practices would enable caregivers to be constituted as active, participative, empowered and reflective subjects. Final Considerations: team practices interfere with caregivers' ways of acting and being and they have implications in objectification and subjectification processes.
\end{abstract}

Descriptors: Caregivers; Home Care Services; Home Nursing; Practice (Psychology); Learning.

\section{RESUMO}

Objetivos: analisar as práticas da equipe de atenção domiciliar e suas implicações na atuação dos cuidadores. Métodos: estudo qualitativo com dados obtidos de observação a 21 usuários, 30 cuidadores e 6 profissionais do Serviço de Atenção Domiciliar em saúde em um município de Minas Gerais, no período de fevereiro a junho de 2018. O material foi analisado na perspectiva da análise do discurso segundo Michel Foucault. Resultados: as interferências da equipe sob o cuidador são exercidas por práticas disciplinares, condutas prescritivas, impositivas e de vigilância. A relação de saber-poder da equipe determina a aceitação do cuidador pelo convencimento ou pela dificuldade de compreensão das orientações transmitidas. As práticas educativas possibilitariam a constituição do cuidador como sujeito ativo, participativo, empoderado e reflexivo. Considerações Finais: as práticas da equipe interferem nos modos de agir e ser do cuidador, possuindo implicações nos processos de objetivação e subjetivação.

Descritores: Cuidador; Serviços de Assistência Domiciliar; Assistência Domiciliar; Prática (Psicologia); Aprendizagem.

\section{RESUMEN}

Objetivos: analizar las prácticas del equipo de atención domiciliaria y sus implicaciones para el desempeño de los cuidadores. Métodos: estudio cualitativo con datos obtenidos de la observación de 21 usuarios, 30 cuidadores y 6 profesionales del Servicio de Atención de la Salud a Domicilio de un municipio de Minas Gerais, febrero a junio de 2018. El material se analizó desde la perspectiva del análisis de la discurso según Foucault. Resultados: las interferencias del equipo a cargo del cuidador son ejercidas por prácticas disciplinarias, conductas prescriptivas, impositivas y de vigilancia. La relación conocimiento-poder del equipo determina la aceptación del cuidador al convencer o por la dificultad de comprender las pautas transmitidas. Las prácticas educativas permitirían al cuidador constituirse como un sujeto activo, participativo, empoderado y reflexivo. Consideraciones Finales: las prácticas del equipo interfieren en las formas de actuar y ser del cuidador, con implicaciones para los procesos de objetivación y subjetivación.

Descriptores: Cuidadores; Servicios de Atención de Salud a Domicilio; Atención Domiciliaria de Salud; Práctica (Psicología); Aprendizaje. 


\section{INTRODUCTION}

The epidemiological transition experienced in the $20^{\text {th }}$ century by the Brazilian population changes the pattern of health and disease in the country, with a decline of acute and infectious diseases and an increase in chronic diseases and external causes, which imposes new demands on the health system ${ }^{(1)}$. Home care presents itself as a possibility in a new model that triggers different subjects and care practices beyond those traditionally instituted, fostering the team-user-caregiver participation ${ }^{(2)}$.

Home care services offered by the Unified Health System (SUS - Sistema Único de Saúde) are ruled by Ordinance 825 of April 2016, which regulates Best at Home Program (Programa Melhor em (asa). In this Program, availability of a caregiver who is responsible for home care is required, be it a formal caregiver, i.e., a person who performs health assistance activities for remuneration, or an informal caregiver, who is unpaid, thus being, normally, a patient's family member and not a professional(3).

Studies indicate that, in the country's current reality, Best at Home Program caregivers are mostly informal ones, with a caregiver-user bond marked by family relationships ${ }^{(4)}$ and who interpret care as a mission strengthened by the feelings they have for their family members ${ }^{(4-5)}$. However, studies do not explicitly demonstrate how a home care team, through its practices that involve relationships and actions, impacts caregivers' performance.

In this context of relationship with caregivers, a home care team has the fundamental role of managing care practices, ensuring that caregivers are committed to assistance and that they carry out actions established in an articulated care, promotion and prevention plan, whether it is for individual or collective subjects ${ }^{(6)}$.

However, it can be assumed that this relationship is permeated by power relations that are expressed through conflicts and disputes that characterize knowledge-power relationships between professionals and caregivers, which can interfere in provided care practices. In Foucault's perspective, one of the forms of expression of power resides in discipline, or disciplinary power, which acts by creating norms for everyday human activities and submitting individuals to them, with the aim of producing docile and submissive bodies, which constitute the useful individual for a given society ${ }^{(7)}$.

Foucault studied different social institutions and found that they function as places for the configuration of disciplinary practices, as they are able to combine, control and shape individuals, producing subjections ${ }^{(8)}$. These institutions compose disciplinary societies in which knowledge-power techniques are established for the control of individuals, which lead them to think, act and be in a certain way ${ }^{(7)}$, which has an impact on their daily practices.

Discipline has the power to configure subjects and act on their bodies in a process of normalization ${ }^{(9)}$. In disciplinary societies, the mechanisms for monitoring established norms and rules subject individuals to constant judgment and imposed penalties ${ }^{(7)}$. In this combination, there is also the examination that, at the same time, monitors, qualifies, rates and punishes, making it possible to extract information, knowledge and truth about individuals $s^{(7)}$.

In the dynamics of the constitution of subjects, objectification and subjectification are complementary processes that are related through what Foucault called games of truths ${ }^{(10)}$. In this process of subject constitution, there will be forces that tension towards subjecting individuals to the standard established by norms and rules, or towards the creation and recognition of the self ${ }^{(10)}$.

Based on this problem, it is assumed that caregivers, in home health services, constitute themselves as subjects in the meetings that occur with the health teams due to home care. It is an important justification that there is a need to verify how team practices interfere and mobilize caregivers' configuration and, on the other hand, how caregivers also interfere in the production of care based on the relationships they establish with themselves, when regulating and modifying the experience of themselves and their recognition as caregivers. This analysis is relevant because the presence and performance of caregivers is essential for users' permanence in home care services and, in some cases, they are essential for admission to the home.

\section{OBJECTIVES}

To analyze the practices of home care teams and their implications for caregivers' performance at home.

\section{METHODS}

\section{Ethical aspects}

The investigation respected the ethical precepts for research involving human beings, according to Resolution 466 of December 12,2012 , with all participants signing an Informed Consent Form. The project was approved by a Research Ethics Committee. To ensure anonymity, study participants were coded. Professionals received the letter $\mathrm{E}$ and a number; caregivers were identified with the letter $C$ and a number; and patients/users were coded with the letter $U$ and a number. The researcher received the letter $\mathrm{P}$ as a code. The project was presented to the coordination of the Home Care Service that authorized study conduction and intermediated the researcher's contact with the studied team.

\section{Type of study}

This is a qualitative research, as it makes it possible to understand the phenomena in their daily context and the relationships in their environment and life and work processes ${ }^{(11)}$.

Communicating the results of this research followed the COnsolidated criteria for REporting Qualitative research (COREQ) guidelines.

\section{Methodological procedures}

Participatory observation was adopted for data collection, manually recorded in a field diary (DC) and later transcribed to digital medium. The relationships and interactions between professionals, caregivers and users were recorded.

Team home visit was monitored, whose objectives were recruitment, admission, routine care, discharge and post-death of service users. In this process, the focus of observation was the caregivers' relationship with the team. Observation sought to capture elements of the contexts (aspects of the home, the way 
the team works), as well as caregivers' actions and reactions, especially the way they received orientations, participated in actions during the team visit, and responded to professionals' demands.

\section{Study setting}

The study was conducted at a Home Care Service (HCS) located in a large city in Minas Gerais State, Brazil. This service has 24 teams, of which a team was appointed for the study, being the only one that assists users with diagnoses and profiles that indicate a need for long-term care, such as chronic obstructive pulmonary disease and degenerative neurological disease; and using respiratory support, such as mechanical ventilation, oxygen therapy, or in need of bronchial hygiene.

\section{Study participants}

Those responsible for user care were considered eligible for the study, which may be in a formal or informal caregiver capacity, in addition to team professionals. It is noteworthy that the sampling process was intentional, with identification of typical cases covered by the service. The option to include caregivers, users and professionals reflects the understanding that these participants interfere in the constitution of caregivers, since subjectification occurs when subjects establish relationships with themselves and with others in a given relationship of knowledge and power ${ }^{(10)}$.

Users and their caregivers followed at home by the HCS team during the data collection period, who were over 18 years of age and who agreed to participate in the study were included. Those who were unable to respond to the survey instruments were excluded. Regarding the professionals, it was decided to include all team members. There was no refusal by caregivers and professionals to participate in the study.

In total, 21 users, 30 caregivers and six professionals were included: a physician, a nurse, a physiotherapist, an occupational therapist, and a nutritionist. It is important to highlight that a user could have more than one caregiver, given the profile of users included in the study, characterized by complex chronic conditions with high care demands.

\section{Data collection and organization}

Data collection was carried out by a researcher, trained in the health field and experienced in the procedures at use, both with regard to the collection techniques and the methodological reference. As it is an intersubjective field, the interactions and relationships built during data collection affected and were affected by the researcher. However, it was sought to carry out few interferences during the field work, in order to provide the free exposure of participants, in reports about their daily lives and about the experiences they had regarding their care practices. Data were obtained from participatory observation, during 30 home visits to 21 users, who were cared for by 30 caregivers, from February to June 2018.

Sixteen users were observed on a single visit; two users were visited twice; two others received three visits and one user received four visits. The team planned work shifts according to users' care demand, which may change if any patient presented clinical instability, social demands, or if there was an admission. Therefore, the number of visits per user was determined by the dynamics of monitoring the work with the team. The criterion of data repetition was considered for collection completion. In total, 60 hours of fieldwork were carried out.

\section{Data analysis}

Data analysis was supported by the discourse analysis framework, based on Michel Foucault's conceptual basis ${ }^{(12)}$. We tried to capture the perspective of spoken things, what was meant, the underlying elements, their constitution, the differences ${ }^{(12)}$. Through discourse analysis, we sought evidence of inversion principles that allow us to see the negative game of discourse cut and rarefaction, the discontinuity to capture what can be ignored, intercross and even exclude the specificity, because it is in practice that events and exteriority are captured, their appearance, their regularity ${ }^{(12)}$. Still, the author reminds us that statements position subjects, whether those who produce them or those to whom these statements are directed ${ }^{(12)}$.

Data processing took place by organizing the material for interpretation of speeches. In this process, each corpus of the observation reports was read and it was sought to identify the statements that referred to the central questions of the study.

A systematic process was built for this analysis, using the transcribed text in Word and pointing, in a side column, the elements of the discursive formation: object, space and relations. In the end, we sought the aggregation and segregation that the set of these elements pointed out.

\section{RESULTS}

Of the 21 monitored users, 17 were elderly, one was 41 years old, and three were between 15 and 29 years old. Nine of these users were dependent on skills for self-care in basic and instrumental activities of daily living; four were deemed partially dependent, and eight were considered independent for activities of daily living. The ADL classification was provided by the team using the Katz Index.

Thirty caregivers participated in the study, who were mostly informal ones (27) and maintained family ties with users (eight daughters, four wives, three mothers, three sons, two granddaughters, two husbands, a nephew, a grandfather, a sister, a daughter-in-law, and a niece). Twenty-three caregivers were female and six were male. Most (23) were in the 20-to-59 age group and seven caregivers were elderly people who cared for other dependent elderly people.

During field work, it was possible to accompany the team on admission, post-death and routine visits, in addition to meetings to discuss cases. Most of these consultations were performed by a physician, alongside a nurse, who assessed users' clinical and functional conditions and, if necessary, monitoring of professionals from the home care support team was requested.

It is up to caregivers to monitor care sessions and take on the team's commands to carry out daily care, such as: food, hygiene, measurement of vital data, control of medication, change of position, bed comfort, wound dressing, among others.

It was possible to identify that home care professionals' performance is directed towards the prescription of care actions and 
guidance to caregivers. In most cases, it was found that the educational actions produced by the team are vertical, focusing on the sick body. It was also possible to perceive that they act through informative guidelines about the service's rules, in a regulatory and directive way.

\section{- C30: using oxygen is important, right?!}

- E6 agrees and repeats three times: it is essential, because otherwise there will be a necrosis, the tissue dies. Due to the deformation of red blood cells, hemoglobin is produced abnormally, with hemoglobin responsible for carrying oxygen from the lungs to the rest of the body. (C30)

E5 measured blood pressure, explained that the lack of fat reserve was bad. Subsequently, he made the request for evaluation by the nutritionist, the prescription of all medications, explained the indication of all of them, the quantity, the validity of the prescription and delivered it to the caregiver. (E5)

The team makes use of health-specific expressions and terms during the guidelines and commands. Discourse using technical terms generates the effect of professionals' knowledge-power on caregivers, causing their acceptance due to lack of knowledge. The regulatory character is verified, in which the speech strengthens the prescriptions established by the team to convince them of the importance of following the commands.

The prescriptive process is associated with informative actions. The team's actions, at this time, focus on guidance, clarifying doubts and answering questions, in addition to registering the therapeutic prescription. In general, the guidelines include information on diets, physical and ergonomic activities, use of medication, change of position, use of manual resuscitator, time of use of the oxygen device, equipment hygiene, aspiration of airways, and necessary actions in case of complications.

Professionals guide, prescribe, demand explanations and answer questions. Thus, they make inquiries to analyze and understand the case, clinically assess users, prescribe and inform care actions and guidelines necessary for care follow-up. Sometimes they ask caregivers to perform certain procedures.

E2 explains about each medication, what it is for and what are their times of use.

-E2: who can get these drugs?

- U1: anyone.

- E2: it will be necessary to purchase the medicine today, as the health clinic will not work during the carnival period.

- U1: but, he doesn't have [the medication] because he didn't warn me. Because there's always someone to pick it up. He didn't warn me.

E2 initiates guidance on the use of medications and asks a caregiver to repeat all guidelines. At the end of service, explains about the process flow for the acquisition of respiratory equipment through SUS. (U1)

E2 guides $C 5$ on using manual resuscitator. E2 measures blood pressure, saturation, and inquires about the situation of the wound on the gluteus.

\section{- C5: it is healed. \\ - C9: what to do if there is a power outage at home? \\ - E2: you have the UPS, and points to the equipment. It acts as a backup battery. (C5 and C9)}

The team passes on a variety of information to guide caregivers on operating the program, the services provided by the team, useful locations, phone numbers to contact in case of doubts and urgencies. They also inform the availability and action flows for obtaining equipment and medications, and provide guidance on the scheduled service time for each user, in addition to the inclusion, exclusion and discharge criteria.

Regarding caregivers, the team also transmits commands regarding their responsibility to users and the procedures for calling on the team, in case of complications.

- E1: how is the U14 routine in your daily life?

- C24: he doesn't sleep well at night and, for this reason, in the morning, we let him sleep until $9 \mathrm{am}$. Then he takes a shower. Once $a$ week we bathe in the shower and the rest is a bed bath. We clean the wound, then put it in the sun.

-E5: what is the name of the drugs used by the patient?

C27 takes the medication and the patient's folder. C24 talks to the physician, who asks again what the night is like.

- C24: he doesn't sleep, he has trouble sleeping. During the day, he only takes a nap, but it is very light. He wakes up for anything. He has shortness of breath when lying on his side. (C24)

It was also found that caregivers were considered to have acquired knowledge at the time of hospitalization, prior to admission to HCS. This period favors the understanding and adaptation of caregivers to health terms and health practices.

It should be noted that information transmitted by the professionals is based on caregivers' prior knowledge. However, each caregiver has their own process of knowledge acquisition, at different times and moments. There is information that requires understanding, decoding and interpretation of support materials by caregivers so they can carry out the activities.

In the orientation process, personalized information forms were made available for each user, filled in by the team at visit time. This strategy was established in order to adjust information organization capacity according to the reality of each caregiver or user. The team seeks, in addition to passing on information, to include the performance of activities in the presence of caregivers, explaining the procedures. This allows them to observe and repeat the activities required by care provision.

- C27: that the manual resuscitator has arrived.

-E2: C27, would you have a cap for an isotonic drink? It fits snugly into the manual resuscitator valve assembly insert.

C27 takes hold and E2 shows how to fit the lid. Relatives [grandmother, grandfather, nephew and wife] are present. They state 
that they would like to learn, so they can help the primary caregiver. (C27 and E2)

- E2 shows for C20: this is the sheet with the times, dosage and day of each medication. E2 explains the amount of medication she should be taking each day and guides how they should follow the sheet. The physician takes the sheet and shows it to the patient and, again, guides how to proceed. Professionals post the paper on the refrigerator. (C20 and $\mathrm{E} 2$ )

- C2: can I film how you perform the wound care? So, I can follow up later, where and how to pass each item.

- E6: you can. The nurse does the procedure and guides caregivers as it should be done. Explains where the hydrogel, oil and cream should go and explains the cream functioning. (C2 and E6)

The team conducts the most complex guidelines at the beginning of visit, with the performance of new procedures, techniques or conducts in case of user instability. In these moments, a caregiver is invited to follow a professional' work to perform some actions, in order to confirm their understanding of what was taught or oriented. In routine visits, the team sometimes directs verbal instructions to caregiver or to user.

The team $[\mathrm{E} 2, \mathrm{E} 5]$ makes the second visit to the patient. During this visit, the team advises the caregiver on how to perform the aspiration, the procedures in case of decannulation, contacting the service and the Ambulance Service [SAMU], as well as the situations that must be referred to the Emergency Unit [EU] or the Hospital. Professionals also inform the care and protection of the gastrostomy, advising on hand washing and stoma cleaning. They explain that, in case the catheter is displaced or removed, the diet should be suspended and the service should be called for the necessary measures. Finally, professionals guide skin care. At this point, the caregiver informs that the patient's groin is red. E2 asks men to leave the room to evaluate the groin, guides the care and leaves an order of ointment to protect the affected area. (E2 and E5)

In admission and routine visits, prescriptive practices were more intense. In the inclusion of users, professionals turn to the understanding and survey of users' clinical history, context of life, and service presentation. Routine visits make professionals focus on repeating guidelines, checking medications, device parameters, and ordering tests.

It was observed that the information is passed on as a prescription, a therapeutic plan prepared by the team with its set of guidelines. This type of action provides a feeling of "security" for professionals, as they believe they have "taught" caregivers what to do, disciplining them.

As a way of assessing compliance with what was prescribed, some control mechanisms are established, such as the routine of checking the number of medications used, the system of respiratory equipment, the evolution of users' clinical condition, especially those with injuries.

- E2: the wound in the gluteus, how is it?

-C28: it is healed.

\section{-E2: I will look and evaluate. (E2)}

E5 asks P13 to sit down to check the saturation. After checking, notices that saturation is 54 .

C28 goes to the room to get $\mathrm{O}_{2}$.

- E6: Are you using oxygen?

- C28: P13 is resistant to the use of oxygen.

- E6: is she using oxygen and the mechanical ventilator?

- C28: She doesn't like to use it, I need to be in control all the time. [...] and she is feeling weak. It is because of the food, because you cannot eat much because of diabetes.

- E5: she is weak from lack of oxygen, from the low amount of oxygen in her blood. Her saturation is too low. Another thing, every time we come here, we guide the issue of the slipper. The use of this slipper increases the risk of falling. (E5)

Although the prescriptive character prevails for routine cases, the perspective and the conduction of the team's practices change in the face of alterations in patients' condition, when there is some complication or when there is a conflict in the relationship with caregivers. In the latter case, the team seeks to negotiate, through dialogue, listening, convincing and raising awareness.

During the fieldwork, no educational intervention was observed, in favor of strengthening the actions carried out by caregivers, or of emotional and psychological support for these subjects.

\section{DISCUSSION}

In order to understand home care team practices and their interference in the performance of caregivers at home, we rely on the post-structuralist framework, according to which it is understood that "the processes of subjectification refer to the way the man understands himself as a legitimate subject of a certain type of knowledge" ${ }^{\prime \prime(9)}$. Thus, by subjectifying himself, man constitutes truths, creates regimes of truth produced by power and norms, and creates himself as a subject by the effect of these truths. After all, the discourse of truth brings with it the effects of power by establishing relations of domination, judgment, and order, determining a social norm of how to live and behave ${ }^{(13)}$.

In the context of home care, this perspective can be understood when caregivers feel socially obliged to take on certain behaviors by subjecting themselves to certain established truths, which are represented by dictated norms and rules, i.e., by discipline. In this sense, it was observed that the service rules are assumed to be, by the home care team, as established truths, and they are structured in the form of information and guidelines to be followed by users, constituting elements of daily care at home. However, it is worth considering that these elements act as stressors, generate anxiety, depression, overload related to the lack of self-care and sharing of activities ${ }^{(14-16)}$.

The fact that caregivers are mostly women and have a parental relationship influences the results of this study, since 23 caregivers 
were women and, of them, 20 had some kind of parent-child relationship with the individual being cared for. In this regard, other studies indicate that the degree of kinship, gender (female) and physical and emotional proximity are factors related to acceptance of the role of caregivers ${ }^{(17-19)}$.

Family caregivers, in general, take on this function in retribution or for moral obligation, due to the imposition and subjection to what is expected of this subject in established social relationships, especially in family hierarchy and social composition ${ }^{(20)}$. The context of family care is stressful, with risks for the physical and psychological health of caregivers, and, in some situations, it can lead to a high level of overload, with sleep disorders, stress, physical and mental fatigue, anxiety, among others ${ }^{(21)}$.

The complexity of care provided in the context of home care was perceived as a factor that requires the development of learning strategies by caregivers, such as, for example, the filming of certain procedures. Allied to this complexity and the accumulation of caregiver functions, changes in the patients' rest hours, with inversion of the day and night shifts, generate a consequent impact on caregivers' sleep habits.

In view of this, it is recommended that team actions during home care be carried out in an integrated manner, permeated by the multidisciplinary perspective of support, considering the vulnerability of caregivers and other family members as subjects who are responsible for users ${ }^{(22)}$. Furthermore, it is expected that the work in $\mathrm{HC}$ provides psychological and social support that allows caregivers to deal with mental and emotional changes in a healthy way, through understanding, acceptance, the creation of coping mechanisms and means to avoid overload ${ }^{(21)}$.

The results inform that there is a predominance of attention centered on the team with guidelines of a biological nature and focus on wound dressing. As a result, actions are still centered on overvaluing behavior control strategies ${ }^{(23)}$. Similarly, in most cases, it was possible to notice that the team produced verticalized educational actions, in a regulatory and directive manner. These action mechanisms facilitate the control of caregivers' conduct, in a disciplinary exercise.

In this sense, the effectiveness of discipline is due to the use of three instruments in the production of docile and useful bodies: hierarchical surveillance, normalizing sanction and examination ${ }^{(7)}$. Hierarchical surveillance allows disciplinary power to become an integrated system, through the attentive and vigilant look of all individuals in a social structure, establishing a flow of power where everyone watches and is watched ${ }^{(7)}$. However, in order to guarantee compliance with the norm, it is always accompanied by a form of sanction, called a standardizing sanction, which constitutes a system of penalties to which all who depart from it are subjected ${ }^{(7)}$. Through examination, control that normalizes and surveillance that qualifies, rates and punishes ${ }^{(7)}$ are both established.

The disciplinary character can be observed in the prescriptive profile of guidelines aimed at caregivers and users. It is also worth considering that the guidelines are structured based on rules and norms of service, which define the criteria for caregivers to be considered ideal in the context of current health practices. The rules are clearly defined and are constantly presented by the team and, in order to guarantee compliance, a constant surveillance cycle is established through the team's disciplinary eye, but also through mutual views between users and caregivers, which is a cause for conflict in day-to-day care.

It was observed that, in many moments, there was normalization, in a perspective that gives little value to the experience of caregivers, de-potentializing subjectivity through self-practices. These practices, if valued, would allow caregivers self-knowledge, self-exercise and improvement. When there is an emptying of the experience, caregivers are empty as well, which leads to their "de(sin)formation". At most, there is a repetition of commands, common and routine actions, without reflection. On the other hand, focusing on experience is a vital aspect "for the construction of a network of therapeutic resources that must be systematically established" and that considers caregivers as partners that need to be heard and understood ${ }^{(13)}$.

However, attitudes of indifference and decentralization of caregivers were observed in relation to the established processes, which can be understood as a form of normalizing sanction, of the penalty imposed on caregivers for not strictly following all the rules imposed. This is a characteristic of knowledge-power practices and their multi-directionality, which are spread in different ways, such as micro-powers ${ }^{(24)}$. These ramifications were present in the observed scenes and indicate the centrality of technical and scientific knowledge coming from professionals. Power relationships and their effects were also observed from caregivers and their domain knowledge: the context, users' needs and desires.

One way of expressing the power-knowledge relationships that are established between health professionals, users and caregivers in home care is the lexical selection of professionals, which is loaded with technical terms, specific to the health area. The use of medical jargon tends to position users and caregivers as subjects who are responsible for the care process, for making use of their power and knowledge to promote user compliance and adequacy ${ }^{(25)}$. It is also emphasized that even if there is no primary intentionality, knowledge means otherness, and it is through experience that objects of knowledge are delineated ${ }^{(26)}$.

It was evidenced there was a constant reinforcement of informative guidelines of the service rules, with the use of specific expressions and terms of the health area, establishing an effect of knowledge-power, of acceptance, making caregivers accept the determinations by convincing them or by the very limitation of their understanding. The process of instructing caregivers to perform procedures takes place through the repetition of commands by the team and subsequent demonstration by caregivers of their understanding.

It is important to consider that the relationships established between the team and users and caregivers do not take place passively, without resistance from some in relation to the attitudes and behaviors of others, establishing a game of forces and resistances. This resistance needs to be understood, as it results from the practices of freedom, through the questioning of identity, the search for subjectivity, rescuing the subject, the way of existence, the practices of the self, the production of the self, the ethical, aesthetic form and politics of subjects in the world ${ }^{(27)}$. Therefore, there is room for health education actions, with strategies that encourage learning. 
Preparation to act in home care depends on caregivers' previous knowledge and on the way the team absorbs and refreshes this knowledge. Thus, the experience and degree of commitment to the reality experienced by each caregiver is unique and should be taken as contributions to an educational process that meets the needs of each subject, in this process ${ }^{(28)}$.

The results of this study indicate that home care team practices interfere with caregiver constitution, either through the mechanisms of objectification or through subjectivation. Directly, there is interference upon caregivers' actions directed by discipline, surveillance, control and examination. The HCS team experiences a complex situation, with regard to the pedagogical practice developed for guidance, support and constitution of caregivers. The practices used by the team require strategic actions, time, determination, flexibility and focus on interpersonal relationships and interactions.

Home care team interferences also converge to caregivers' way of being by enabling the reflection, displacement and deterritorialization that occur in encounters with others and that have provided historically unique experiences, listening to oneself and the other, and that relate the fields of discourse, power and knowledge in shaping practices.

In this way, AD is also an open space for subjecting experiences, in subject caregiver constitution, when there are effective meetings, openness to problematizations, dialogues, and when a relationship of trust is established between professionals, users and caregivers. Thus, professionals are potent subjects in and for the production of caregivers, when they use mechanisms that enhance their training and their performance as caregivers and, consequently, their performance with users.

\section{Study limitations}

The results obtained may have been influenced by the circumstances of organization of the studied team and the profile of patients under care. For these limitations, it would be pertinent for future works to analyze other types of team with different characteristics.

\section{Contributions to nursing}

The study made it possible to understand a perspective regarding practices related to HCSs. The HC team is composed mainly of nursing professionals and these professionals are also active in contact with caregivers, mediating the team's work, guiding the actions and preparing them for home care.

Thus, the results have the potential to contribute to the development of a learning process for caregivers that respects previous knowledge, acquired accumulations, but also promotes their potential as subjects of care. HCS professionals should work with strategies that encourage self-practice and knowledge of themselves, considering caregivers as potent subjects. There is a need to create space and time for caregivers and teams to discuss the dilemmas and challenges of everyday practice at home. It is necessary to establish moments and movements for reflection, externalization of caregivers' and professionals' concerns, developing subjective experiences.

\section{FINAL CONSIDERATIONS}

The interference of home care team practices on caregivers, as well as these caregivers' actions on the team's practices, have repercussions on caregivers' life and learning as a subject.

The results indicate that there are practices to discipline caregivers' conduct at the time when they provided guidance on care, when they requested the performance of procedures for validation, and when they determined the acquisition of equipment for users, which has implications for the care practices developed by caregivers at home. Other identified practices were prescriptive. The teams generated interference with more vertical actions, using behavior control and surveillance mechanisms. Disciplinary, control and surveillance practices tend to objectify caregivers' behavior. These practices are based on a hierarchical, normative and verticalized knowledge-power relationship, with little space to problematize the reality experienced in caregivers' daily life.

It can be said that the aim of this study was achieved, making it possible to conclude that team home care visit enabled the subjectivation of caregivers. In this sense, it can be said that the relationship between the team and caregivers is permeated by subjective experiences, which touch and enable individuals formation and transformation.

As practical implications of this study, we can indicate that the constitution of caregivers is a continuous process. The subject is a being that is always under construction and, thus, the team can provide moments of reflection with caregivers, establishing times and movements so that experiences can emerge through which they learn about who they are, their position, the role they play. For this, it is indicated the creation of partner networks for emotional and psychological support of caregivers, which contribute to the learning process and that allow caregivers time for themselves and for carrying out care actions.

\section{ACKNOWLEDGMENT}

Federal University of Minas Gerais, Graduate Program of Nursing for providing the funding by CAPES.

\section{REFERENCES}

1. Oliveira SG, Marossi LM, Spaziani AO, Frota RS, Monteiro STF, Paulino ASM, et al. Epidemiologia da doença reumática crônica cardíaca no Brasil nos anos de 2014 a 2018. Braz J Health Rev. 2020;3(1):857-72 https://doi.org/10.34119/bjhrv3n1-068

2. Weykamp JM, Siqueira HCH, Cecagno D, Medeiros AC, Paula SF, Pedroso VSM. Home Care Service and Health Care Networks. Rev Pesqui Cuid Fundam. 2019;11(5):1117-21. https://doi.org/10.9789/2175-5361.2019.v11i5.1117-1121 
3. Ministério da Saúde (BR). Atenção domiciliar no SUS: resultados do laboratório de inovação em atenção domiciliar. Organização PanAmericana da Saúde. Brasília (DF); 2014.

4. Garbaccio JL, Tonaco LAB. Characteristics and difficulties of informal caregivers in assisting elderly people. Rev Pesqui Cuid Fundam. 2019;11(3):680-6. https://doi.org/10.9789/2175-5361.2019.v11i3.680-68

5. Ribeiro BF, Oliveira SG, Tristão FS, Santos Jr JRG, Farias TA. Práticas de si de cuidadores familiares na Atenção Domiciliar. Rev Cuidarte. 2017;8(3):1809-25. https://doi.org/10.15649/cuidarte.v8i3.429

6. Lopes CVDO, Vilasbôas ALQ, Castellanos MEP. Home care in the family health strategy: implementation degree analysis in the city of Camaçari (BA). Saúde Debate, 2017;41,(3):241-54. https://doi.org/10.1590/0103-11042017S318.653

7. Foucault M. Vigiar e Punir: nascimento da prisão. Tradução de Raquel Ramalhete. 42. ed. Petrópolis, RJ: Vozes; 2014.

8. Garcia E, Grisotto A. Novas formas de controle biopolítico: uma leitura a partir de Foucault. Argumenta J Law [Internet]. 2018 [cited 2020 Sep 21];(28):79-105. Available from: http://seer.uenp.edu.br/index.php/argumenta/article/view/1234/pdf

9. Foucault, M. Política e Ética: uma entrevista. Ditos e Escritos V: In: Ética, Sexualidade e Política. Rio de Janeiro: Forense Universitária; 2014.392 p.

10. Castro E. Vocabulário Michel Foucault. 2 ed. Belo Horizonte: Autêntica; 2016. 447 p.

11. Minayo MCS. Pesquisa social: teoria, método e criatividade. Petrópolis, Rio de Janeiro: Vozes; 2016. 109 p.

12. Foucault M. A ordem do discurso: aula inaugural no Collège de France, pronunciada em 2 de dezembro de 1970. Tradução de Laura Fraga de Almeida Sampaio. São Paulo: Loyola; 2013.

13. Torres JWL. Poder e discurso a partir de Michel Foucault: breves análises sobre a genealogia do biopoder. Contemporânea - Rev Ética Filos Pol [Internet]. 2016 [cited 2020 Sep 21];3(1):62-82. Available from: https://revistacontemporanea.fafica-pe.edu.br/index.php/ contemporanea/article/view/27/35

14. Del-Pino-Casado R, López-Martínez C, Serrano-Ortega N, Pastor-Bravo MDM, Parra-Anguita L. Obligation and negative consequences in primary caregivers of dependent older relatives. PLoS ONE. 2018;13(9). https://doi.org/10.1371/journal.pone.0203790

15. Del-Pino-Casado R, Palomino-Moral PA, Pastor-Bravo, MDM, Frías-Osuna, A. Determinants of depression in primary caregivers of disabled older relatives: a path analysis. BMC Geriatrics. 2017;17(1):1-9. https://doi.org/10.1186/s12877-017-0667-1

16. Oliveira, SCC, Moura, PR. Análise reflexiva sobre a capacidade de autocuidado dos cuidadores domiciliares. Rev Fac Ciênc Méd-Sorocaba. 2017;19(1):15-18. https://doi.org/10.5327/Z1984-4840201727022

17. Neves ACOJ, Seixas CT, Andrade AM. Atenção domiciliar: perfil assistencial de serviço vinculado a um hospital de ensino. Physis. 2019;29(2):290214. http://dx.doi.org/10.1590/s0103-73312019290214

18. Magagnin AB, Heidemann ITSB. Empowerment do familiar cuidador frente ao acidente vascular cerebral no ambiente hospitalar. Rev Bras Enferm. 2020;73(4):e20190165. http://dx.doi.org/10.1590/0034-7167-2019-0165

19. Dixe, MACR, Teixeira LFCF, Areosa TJTCC. Needs and skills of informal caregivers to care for a dependent person: a cross-sectional study. BMC Geriatrics. 2019;19(1):255-64. https://doi.org/10.1186/s12877-019-1274-0

20. Silva YC, Silva KL. Constituição do sujeito cuidador na atenção domiciliar: dimensões psicoafetiva, cognitiva e moral. Esc Anna Nery. 2020;24(4):20190335. https://doi.org/10.1590/2177-9465-ean-2019-0335

21. Delalibera M, Barbosa A, Leal I. Circunstâncias e consequências do tratamento: caracterização do tratamento familiar em cuidados paliativos. Ciênc Saúde Colet. 2018;23(4):1105-17. https://doi.org/10.1590/1413-81232018234.12902016

22. Pozzoli SML, Cecílio LCO. Sobre o cuidar e o ser cuidado na atenção domiciliar. Saúde Debate. 2017;41(115);1116-29. https://doi. org/10.1590/0103-1104201711510

23. Procópio LCR, Seixas CT, Avellar RS, Silva KL, Santos MLM. A Atenção Domiciliar no âmbito do Sistema Único de Saúde: desafios e potencialidades. Saúde Debate. 2019;43(121):592-604. https://doi.org/10.1590/0103-1104201912123

24. Lima VMRL, João JBS, Paula MC (Orgs.). Caminhos da pesquisa qualitativa no campo da educação em ciências: pressupostos, abordagens e possibilidades. Porto Alegre: EDIPUCRS; 2018.

25. Baptista MKS, Santos RM, Duarte SJH, Comassetto I, Trezza MCSF. The patient and the relation between power-knowledge and care by nursing professionals. Esc Anna Nery. 2017:21(4)e20170064. https://doi.org/10.1590/2177-9465-EAN-2017-0064

26. Souza PF, Furlan R. The question of subject in Foucault. Psicol USP. 2018;29(3):325-35. https://doi.org/10.1590/0103-656420170057

27. Foucault M. A ética do cuidado de si como prática da liberdade. [Entrevista a H. Becker, R Former-Betancourt, \& A. Gomez-Müller em 20 de janeiro de 1984]. In M. Barros da Mota (Ed.), Ditos e escritos V. Rio de Janeiro: Forense Universitária, 2004.

28. Yamaguchi AM, Oliveira IB. Visita pré-óbito: preparo e atenção frente à iminência do falecimento. In: Assistência domiciliar: uma proposta interdisciplinar. Barueri: Manole, 2010. p. $492-509$. 